Marketing in Asia Group

\title{
Social Media Effectiveness Indicators of Microenterprise Strategic Planning
}

\author{
Alex Cheing \\ Department of Business, Leadership and Management, Briercrest College, Canada \\ Efendi Haslim Hong \\ Faculty of Economics and Business, Atma Jaya Catholic University of Indonesia \\ Thiam Yong Kuek \\ Faculty of Business and Finance, Universiti Tunku Abdul Rahman, Malaysia \\ Boon Hui Bobby Chai \\ Faculty of Business and Finance, Universiti Tunku Abdul Rahman, Malaysia \\ Tat Huei Cham \\ Faculty of Accountancy and Management, Universiti Tunku Abdul Rahman, Malaysia
}

\begin{abstract}
The use of social media in the support of marketing mix has been gaining prominence in contemporary strategic planning. The indicators on how microenterprises can effectively benchmark their social media usage is ambiguous. This paper aims to identify possible indicators of social media effectiveness towards microenterprises strategic planning. A conceptual framework is developed based on marketing mix elements of promotion and place in identifying the possible indicators of social media effectiveness. Owner/managers of food and beverage microenterprises in the Malaysian state of Sarawak were approached to understand their Facebook promotional strategy, features in generating interest to their outlet and general outcome in supporting their marketing mix elements. Through thematic analysis, the findings indicated sales increment, customer retention and viral marketing are vital for social media effectiveness. The context of the paper is limited to microenterprises in developing market through a subjective-based strategic planning evaluation framework. Selective marketing mix elements are applied through the perspective of Food and Beverage industry in the development of the social media effectiveness indicators. The three themes from the findings: sales increment, customer retention and viral marketing could serve as the foundation for microenterprise strategic planning.
\end{abstract}

Keywords: Social Media Effectiveness Indicators, Microenterprise, Strategic Planning, Marketing Mix, Facebook

Publication Details: Received 23 Mar 2020; Revised 8 Apr 2020; Accepted 19 Apr 2020 


\section{Introduction}

The advent of Internet allows enterprises to adopt social media as part of their strategic planning (Wilson et al., 2020; Trainor, 2012). Social media is defined as groups of online-based applications offering two-way communications between senders and receivers in connecting and sharing information (Cheah et al., 2019; Evans, 2012). Some of the world's most well-known social media platforms include Facebook, Instagram, Myspace, Twitter, LinkedIn, Pinterest, Tumblr, WeChat, Snapchat and YouTube (Ting et al., 2015; Zhou et al., 2010). The growing trend of the social media has been further enhanced with the participation of internet users whereby they want to co-create, interact and be involved with the platforms directly. Since then, social media has been acknowledged as one of the powerful marketing tools due to its viral attributes and inclusiveness of both content creator and users that are effective in helping organisations in reaching the mass public (Thackeray et al., 2012).

In addition, social media is also found to have a vast impact on businesses. For example, the past research has shown that enterprises react to these technological and social changes by shifting more to social media usage as opposed to traditional media (Baruah, 2012; Cham et al., 2020; Kaplan \& Haenlein, 2010; Back et al., 2010). It is reinforced by Stelzer (2014) who found out that 92 percent of marketing professionals placed high importance on social media as part of their marketing strategy plan. Among the array of social media platforms, Facebook, founded by Mark Zuckerberg, is reported to have over 1.2 billion users worldwide, thus making it the most popular platform since its humble beginning (Dutta, 2010). In a study by Deepa and Deshmukh (2013), 86 percent of the world's 100 largest enterprises regarded Facebook as an important marketing strategy tool. At such, it is with great interest that this paper focuses on Facebook to gain more insight pertaining to its usage by Malaysian microenterprises (Parveen et al., 2013).

The main appeal of social media usage among microenterprises is access to markets outside their geographical boundaries without the need of actual physical presence (Alarcon et al., 2015). As an emerging economy in Southeast Asia, microenterprises are pivotal to the growth of Malaysia. Despite an array of definition on what constitutes the size of a microenterprise across different regions, the Small and Medium Enterprise Corporation of Malaysia (SME Corp, 2016) describes it as a small business establishment consisting less than 20 employees. Sarawak is the largest state in Malaysia by land size and is known as one of the most promising emerging markets in the country. The state of Sarawak has been actively promoting food and beverage (F\&B) online as one of its unique tourism offerings (Sarawak Tourism, 2019). Despite the conducive business environment policy in the state, little studies were published on how microenterprises in Sarawak strategize social media promotion in tandem with the state government's effort. 
Previous studies of strategy in microenterprises largely revolved around core formulation with dearth of literature on another important part of the overall process: evaluation criteria (Cheing, 2018; Bruton et al., 2015; Bellamy et al., 2013). Above all, little is known about the social media indicators which a microenterprise can effectively benchmark (Hoffman \& Fodor, 2010) away from the complexity of sophisticated strategy models commonly adopted in many large and medium enterprises. The exact measurement of social media strategy which may assist in microenterprise strategic planning as part of overall business performance is still at embryonic stage at present (Valos et al., 2017; Capua, 2012; Akar \& Topcu, 2011). Correspondingly, social media has been an integral part of an important outreach channel for many enterprises, but the exact guidelines referred to by decision-makers in microenterprises to incorporate it as part of their business strategy remain vague and require further investigation.

Hsieh et al (2018) believed that this aversion among microenterprises was attributed to the informal nature of their operations. Owners of microenterprises often do not possess advanced academic qualification or expertise, preferring to rely more on their intuition and prior experience in steering their enterprises towards the desired goals. In view of this gap, this paper serves as groundwork to identify possible indicators of social media effectiveness towards microenterprises strategic planning. This is achieved by proposing a framework based upon strategic planning evaluation criteria of how cohesive different business functions in an enterprise are. The marketing mix elements of promotion and place are selected to represent the business functions while Facebook serves as the proxy for the social media platform.

This paper adopts a qualitative approach to gain detailed insight of how owners or managers of the F\&B outlets used Facebook to promote their offerings and utilised some common Facebook features to generate visits to their place of business. Through an inductive-based thematic analysis, their responses on how Facebook supported marketing mix elements were applied as the preliminary basis for indicators of social media effectiveness.

\section{Literature Review}

\section{Microenterprise Strategic Planning}

Strategic planning entails the periodic process of structured creation of plans towards an enterprise future undertaking (Mazzarol \& Reboud, 2020; Wolf \& Floyd, 2013). In general, businesses which undertake strategic planning start with formulating mission statement, setting the objectives followed by strategy generation and evaluation. These four-step processes are closely aligned with organisational strategic direction to best anticipate future scenarios in enhancing competitiveness (Casillas \& Acedo, 2013). 
In terms of planning evaluation, enterprises often consider criteria such as business mission statement or vision relevance, realistic achievement of the plan, balanced outcome, and completeness of the ultimate outcome and integration of various business functions (Rossi et al., 2018). On the whole, large enterprises often capitalise on the contribution of highly knowledgeable human resource with peculiar know-how on complex strategic evaluation model through their stronger financial resources (Wright et al., 2013).

In contrast, the complexity of developing a basic framework as strategy evaluation is largely circumstantial in microenterprises (Kraus et al., 2011). Mapping the strategic assessment in microenterprises are largely dictated by owner-managers' ad hoc needs or not conducted at all (Bellamy et al., 2013). Not only that, microenterprises often face challenges in accessing niche information or knowledge because of their lower financial and human resource capabilities. For instance, adding a single employee is considered huge monetary constraint in a microenterprise requiring careful consideration while it is trivial in larger enterprises' payroll (Au \& Tucker, 2018). These shortcomings deepen the necessity of evaluating strategic planning in microenterprises due to their distinctive operation styles.

One of the greatest risks for microenterprises is high failure rate. Microenterprises frequently faced higher tensions because of strong micro influence within their operating foundation. Decision-making are often the subject of internal squabbles between various family members or stakeholders ranging from engagement, procedure and affinity. Unless there is a presence of a sole authoritative stakeholder, these likely trigger extended strategic digress which will lead to brief diminishing performance (Bellamy et al., 2013). Outside the owners' level of education and business experience which typically dictate the competitiveness of microenterprises, ineffective planning evaluation is a vital factor which should not be overlooked (Kraus et al, 2011). Existing literature on the planning evaluation are underrepresented in most contemporary studies related to microenterprises (Grunig \& Kuhn 2018; Bryson et al., 2017; Luoma, 2015) either from a marketing or management perspective.

In Malaysia, recent studies discover that planning evaluation is typically ignored among majority of microenterprises (Cheing, 2018; Ho, 2017). From a management perspective, findings by Cheing (2018) indicated planning evaluation is considered an option by owner-managers rather than a necessity. In marketing terms, Ho (2017) revealed the rigidity involved in planning evaluation advocated in most Western countries as too complicated versus the Asian microenterprises' preference for networking as a substitute information source which is deemed more reliable. 


\section{Social Media Effectiveness Indicators}

The metric or indicators for social media have frequently dominated digital marketing literature ranging from domain, social medium and data elements (Roy et al, 2020; Peters et al, 2013). It was widely accepted that microenterprises which perceived social media as an avenue for marketing competitiveness typically performed better as a result of higher customer satisfaction as well as matching competitors' online channel strategies (Ismagilova et al., 2019(a); Pansari \& Kumar, 2017; Minkiewicz et al., 2014). Even with the existence of various social media management software namely Qwaya, Agency Analytics and Agora Pulse (Capterra, 2017) the lack of strategic-oriented metrics assessment in social media effectiveness has long been a pressing issue among microenterprises. This could be attributed to the disagreement on the three major strategic orientations in social media marketing that appeared relevant: marketing mix, entrepreneurial and e-marketing stream (Valos et al., 2017).

In marketing mix, there are essentially seven different functions to target the desired market. Known as the 7Ps of marketing, they consist of product, price, promotion, place, people, physical evidence and process. Product should match customer requirements while representing a good value through its pricing and people who represent the business. Almost all products and services include some physical evidence even if most of what customers are paying for is intangible through the start until the end of the sale process (Kotler et al, 2013). An eighth function, or ' $\mathrm{P}$ ' has been advocated by Chaffey and Chadwick (2012) in recognition of Partners as important functions for enterprises with online presence although critics considered these as a shadow to place in view of the common similarities (Holloman, 2013).

Entrepreneurial orientation was shown to affect social media effectiveness because traits such as risk-taking, proactiveness and innovation mind set were crucial towards leveraging social media for success (Lal et al, 2020; Parveen et al., 2015; Korsten et al., 2013). E-marketing was a contributor to social media success as sophisticated CRM and database technologies were vital in reaching digital consumers (Cham et al., 2018; Kunz \& Hackworth, 2011; Wu et al., 2011) who valued connections, creations, consumption and control in their social media consumption (Cham et al., 2016; Hoffman \& Fodor, 2010). Previous research on the most relevant strategic stream contained mixed results due to unique market environment and synergies (Deutscher et al., 2016; Morgan et al., 2015; Eggers et al., 2013; Shaltoni \& West, 2010). This paper espouses the criteria of planning evaluation based on the marketing mix orientation as it is supposed to best match the nature of Facebook that involves heavy emphasis of promotion and place as illustrated in Figure 1. 
Figure 1: Proposed Framework of Social Media Effectiveness Indicators in Microenterprises

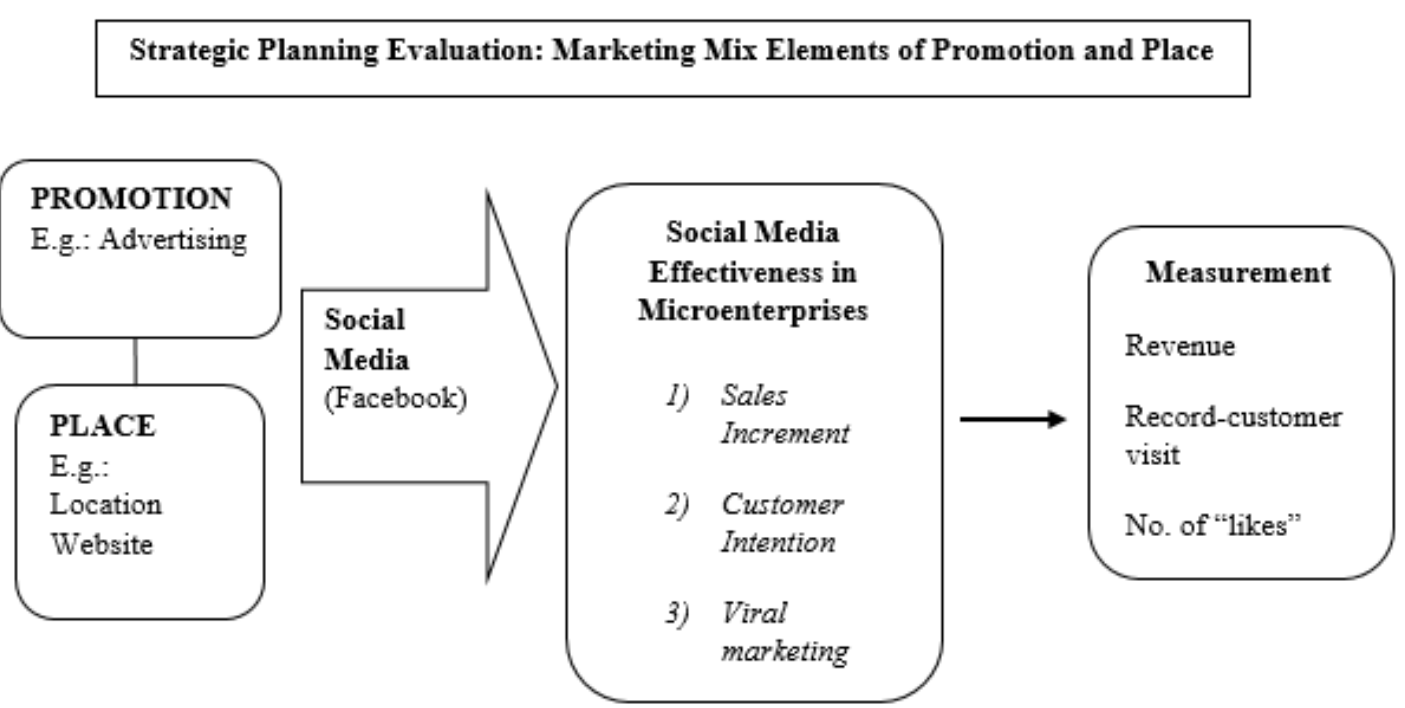

The two functions of promotion and place are particularly connected to Facebook due to the extensive involvement of advertising and website presence (Needles \& Thompson, 2013; Ciprian, 2012; Curran et al., 2011). Facebook is a common promotional tool in $\mathrm{F} \& \mathrm{~B}$ microenterprises primarily due to their tight cost structure (Jaichuen et al., 2019; Klassen et al., 2018). Most often, the use of Facebook by F\&B microenterprises serves to persuade the target audience to communicate the offerings in store as well as soliciting feedback from customers on the various strategic initiatives planned through online two-way interaction between the marketers and customers (Schulze et al., 2014; Bergstrom \& Backman, 2013). Customer feedback is highly sought after as a medium in promoting new offerings or ideas (Snyder, 2013). The interaction through Facebook would enable faster responses to enquiries and comments which are highly anticipated by the customers (Ismagilova et al., 2019(b); Holloman, 2013; Boyd, 2011). On top of that, feedback gathered also allowed F\&B microenterprises to learn what customers are saying about their outlet and take the opportunities to rectify service failures (Kwok \& Yu, 2012). Well-managed Facebook promotion can result in an effective virtual customer relationship and encourage firsttime visits through the constructive contents generated by other customers (Antoniadis et al, 2020; Richards \& Guppy, 2014). A typical Facebook user will follow 4 business or fan pages per month and has average of 130 friends (Baer, 2015). Clark and Melancon (2013) claimed that 51 percent of Facebook users who follow and 'like' a distinct page would likely proceed to purchase intention. As with other social media platforms, there is little control over who can post the information (Pfeiffer \& Zinnbauer, 2010). This created opportunities for saboteurs to circulate damaging comments in nature (Peppers \& Rogers, 2011). 


\section{METHODOLOGY}

A research plan was carefully designed to ensure the rigour of the research process, focusing on the iterative procedure to allow multiple checks (Ting et al., 2019). A generic qualitative approach was implemented as the first step to identify possible social media effectiveness indicators in microenterprises. Based on purposive sampling, the study specifically sought owner or managers of the F\&B microenterprises all over Sarawak based on at least three weekly posts, minimum number of 30 'likes' and had day-to-day involvement in strategic planning. These criteria were adapted to ensure the microenterprises had active Facebook presence and a steady stream of client base. The eligible outlets approached were divided into two phases, the first phase mostly focused on the main urban areas with the highest population, namely Kuching, Miri, Bintulu and Sibu while the second phase search concentrated on semi-urban areas such as Kapit, Mukah, Sri Aman, and Limbang. Once basic eligibility has been established, the outlets were then contacted to establish the presence of strategic planning.

Out of the 63 eligible outlets, 40 agreed to participate but two withdrew and eight outlets which belonged to the same owners had to be removed. The final samples obtained is 30 , comprising owners and managers who were directly involved in the running of business and the use of Facebook. Through a data saturation approach advocated by Marshall and Rossman (2011), the point of redundancy was obtained during the later stage of data collection, rendering the response rate a non-concern. Data were analysed using thematic analysis from the semi-structured interview transcripts.

Participants were asked on the reasons they use Facebook in their business promotion. This is followed by the most common Facebook features which they used to gain further details into how they deployed social media in attracting target segments to their places or outlets. The last section of the interview probed their responses on how well Facebook supported both the marketing mix elements of promotion and place as part of their strategic planning evaluation. The average interview length was approximately 30 minutes covering questions such as 'Why do you use Facebook as a promotional tool?', 'How do you use Facebook features to attract customers?', 'How does Facebook support your marketing promotion?' and 'How does Facebook generate interests and channel customers to your outlet?'.

The thematic analysis began with reading, re-reading and reduction of data gathered during initial immersion stage. Codes were then assigned to the responses given on the effectiveness of Facebook, reasons for using Facebook promotion and Facebook features chosen to attract customer attention. The final stage of analysis involved development of themes through comparison of similarities and differences of the codes. With the assistance of QUIRKOS software, the final themes were devised as shown in Table 1. 
Table 1: Thematic Analysis Outcome

\begin{tabular}{|l|l|l|}
\hline Analysis & Coding & Themes \\
\hline $\begin{array}{l}\text { Facebook effectiveness in } \\
\text { supporting marketing mix } \\
\text { elements }\end{array}$ & $\begin{array}{l}\text { Boost Attendance, Increase Sales } \\
\text { Repeat purchase, Constant Interaction, } \\
\text { Word-of-Mouth (WOM) }\end{array}$ & $\begin{array}{l}\text { Sales Increment } \\
\text { Customer Retention } \\
\text { Viral Marketing }\end{array}$ \\
\hline $\begin{array}{l}\text { Reasons for promoting via } \\
\text { Facebook }\end{array}$ & $\begin{array}{l}\text { Simple User Interface, Marketing Mix } \\
\text { Strategy, Low-Cost } \\
\text { Fast Feedback }\end{array}$ & Marketing Speed \\
\hline $\begin{array}{l}\text { Facebook features used in } \\
\text { generating interest to the } \\
\text { place }\end{array}$ & $\begin{array}{l}\text { Posting, Sharing Information } \\
\text { Soliciting Comments, Feedback } \\
\text { Paid Advertisement Sponsorship }\end{array}$ & $\begin{array}{l}\text { Posting } \\
\text { Paid Ads }\end{array}$ \\
\hline
\end{tabular}

\section{FINDINGS}

\section{Facebook Effectiveness in Supporting Marketing Mix Elements}

Overall, three key themes have been mentioned as being beneficial though the usage of Facebook: customer retention, sales increment and viral marketing. Sales increment primarily came through well-liked signature dish:

...if the taste bud is what customers like... they are already my business's mini ambassadors. Through Facebook ... the positive vibe accelerates ten-fold as compared with a friend telling another friend through casual conversation. $70 \%$ of my sales come from just focusing on the chef's recommendations (FB1).

People (customers) here like the idea of ordering our signature dish...it is a must. It is our main selling point...other accompanying menu options are really just supplementary options (FB4).

Customer retention was noticeably higher as a result of promoting online via Facebook. Continuous engagement after post-purchase provided customers with a higher sense of belonging:

...raving about food in Facebook is a favourite activity among users in Kuching nowadays. You cannot ignore those comments even though some are quite negative. This makes a not-so-happy customer feels appreciated after we acknowledged and find ways to improve... and when this customer comes again, the experience would be much more pleasant. When you come to eat in my place, you are the boss (FB25).

In the same way, viral marketing benefits were immense when existing customers spread the buzz on their positive dining experience through Facebook appraisal:

Most importantly...word of mouth. You believe your friends, right? ... if someone said that the food is delicious through Facebook...it makes you want to come as well when you saw their 'wefie' and the food...this makes my business performs so well (FB14). 
...it is like a psychological advantage. Most Facebook users here simply could not resist the temptations when they saw a post recommending my restaurant especially first-time customers (FB20).

\section{Reasons for Promoting Via Facebook}

The two most common reasons $\mathrm{F} \& \mathrm{~B}$ microenterprises picked Facebook in promoting their businesses were enhanced marketing visibility and speed of communicating. Unlike traditional print media, Facebook promotion typically offered improved marketing visibility as the influence of print media was slowly fading:

...it is not like printed newspapers...you have to go to the newspaper or magazine company...the whole publication process took longer. Many people check about the latest news and happenings from their mobile devices... people almost do not care about accessing news from newspaper nowadays (FB16).

Communication speed was greatly improved through the use of Facebook, especially Facebook Messenger.

...it is convenient, just by one click and you can get all the info you want and beside that, our customers can directly PM (private message) us to ask questions, our menu or even booking with us. All these can be done instantly...way faster than a feedback form provided in-store (FB22).

...society here are like Singapore. Speed is everything. They wanted their requests attended immediately so I had to respond to them instantly, time is gold (FB6).

\section{Facebook Features Used to Generate Interest to the Place}

It was discovered that the two main features of Facebook used in generating customer visits to their places were posting and paid ads. Posting the pictures of the new dish promotion with attractive captions helped to attract customers:

...new тепи ... by Facebook posts...then write some short attractive captions on it. So we can post the food menu and latest offer and we will try to brainwash the customers (the public) to come to our outlet (FB8).

I told our chef to snap a picture of the food right after they finished cooking... we tend to introduce new items on our menu that come with promotion...the customers here love bargains (FB30).

Paid ads were also common to attract customers to the outlet. This was considered an investment and incorporated as part of the operating costs: 
...need to pay a little bit of money.... if you pay for it, it directs to the people that you had targeted... for example, the sponsored words will show at the targeted customers' feeds (FB15).

\section{DISCUSSION}

The usage of Facebook in supporting F\&B microenterprises marketing mix of promotion and place enhanced customer engagement. This supported the notion by Dutta (2010) that Facebook is the leading social media network in the world among enterprises. It is probable that constant interaction through Facebook and its chat application resulted in higher sales as East Asian customers generally demand a higher level of attention when ordering their food. Requests for special dietary or personalised ordering covering food portion, choices of varied toppings such as spicy, fresh cooked with garlic, sweet and sour are uniquely common in Sarawak or Malaysian culinary scene especially involving large groups of customers dining together. This practice is especially prevalent as eating out in a restaurant is always a compulsory social activity by customers hosting or bringing in special guests from outside the town, for instance Peninsular Malaysia or overseas, comprising immediate family members, relatives or business associates. More often than not, the hosts already have a sense of prior familiarity with the menu in the F\&B outlets through their continuous patronage and "inside" connection with the relevant owner, manager or supervisor. In most circumstances, the F\&B management would do everything within their control in order to accommodate this group of special customers. When these demands are taken care of and boosted by food satisfaction level, customers felt reassured who then in turn spread the word about the particular F\&B outlet to their Facebook peers.

However, a new theme emerged as one owner interviewed disapproved the benefit of Facebook believing that offline word-of-mouth was sufficient enough to sustain the business in view of having steady regular customers. This echoed the notion on microenterprise owners who preferred to depend on the wisdom of business experience than adhering to any formal or informal strategic planning (Cheing, 2018; Bellamy et al., 2013). A possible reason could be the semi-rural location of the outlet where the population is typically less than 30,000. This often did not require much online marketing or Facebook promotional effort as the dominant demographic group in the area is mostly Baby Boomer generations who may not be so tech savvy. Besides, most of the residents claimed to know one another through second or thirddegree network in a small radius which reduced the dependency on Facebook. Additionally, the dining choice in these semi-urban locations are limited, indirectly contributing to higher sense of community and concentrated customer loyalty to a single F\&B outlet in the town. 
Facebook has largely taken over traditional print media for F\&B microenterprises as the preferred promotional element in reaching the target segments in Sarawak and Malaysia who are largely media-savvy millennials. The findings in this study reflected the feedback opportunities mentioned in the literature (Bergstrom \& Backman, 2013; Snyder, 2013) as one of the reasons for using Facebook promotion. The reason could be attributed to the high number of $F \& B$ microenterprises in Sarawak vying for market share. As stated by Holloman (2013) acting fast through instant feedback is compulsory to satisfy the anticipation of customers regarding prompt responses. Likewise, the cost of promoting via Facebook was perceived as low-cost which matched the financial situation of F\&B microenterprises, aided by affordable rates of data packages in Malaysia from major Internet service providers.

To ensure steady stream of customers to their places, F\&B microenterprises in Malaysia actively engaged with customers on their Facebook page. This strategy replicated the findings by Clark and Melancon (2013) on the huge potential of purchase intention once a customer likes or follow a Facebook business page. The underlying rationale could relate to the vibrant food culture in Sarawak and throughout Malaysia overall. Eating out is generally inexpensive for all income groups and customers are often on the 'hunt' for well-reviewed F\&B outlets. With the combination of affordability and abundance of $F \& B$ choices, eating out is tantamount with Malaysian way of social gathering. Postings and comments on highlighted menu choices can easily attract 'likes' or 'shares' which lead to more curiosity and subsequently the desire to visit the outlets. This phenomenon also resulted in an active food blogging community in Malaysia.

It is not uncommon to see fully packed F\&B outlets in Sarawak and Malaysia during peak dining hours to the extent prior bookings are sometimes imposed. It is a communal habit among Malaysian customers snapping pictures of their favourite food once served and posting them online. Follow-up comments typically flood the posting thereafter, more so with customers who tag their Facebook friends along the way. This was demonstrated by one F\&B owner who signed up for paid ads for the sole purpose of solidifying the existing customer relationship in accumulating more repeat visits.

\section{Theoretical Implications}

As mentioned earlier the exact indicators on planning evaluation were influenced by various external and internal circumstances in microenterprises (Bellamy et al., 2013; Kraus et al., 2011). Through this paper's choice of marketing mix as the metrics of choice in social media strategic planning effectiveness, marketing mix elements of promotion and place could well function as one of the options in microenterprise planning evaluation especially where the adaptation of social media is high in an emerging market environment. Based on themes generated during the analysis, the indicators for the social media effectiveness could include sales increment, customer retention and viral marketing as the foundation for strategic planning evaluation. The simplicity of the three indicators would suit most microenterprises with the option of 
further developing definite measurement as an evaluation outcome. Some of the recommended measurement criteria for sales increment include sales growth per quarter and monthly revenue. As for customer retention, microenterprises can create a simple record-keeping of customer repeat visits. Viral marketing effectiveness can be measured by tabulating the number of 'likes' towards certain post or feedback on the percentage of customers who visited the outlet after the Facebook post encounter.

\section{Conclusion}

This paper discovered that the usage of Facebook as a social media strategy enhanced repeat customer visits, sales growth and word-of-mouth marketing in F\&B microenterprises. Higher marketing visibility and speed of communication were the reasons for choosing Facebook as a promotional tool which was accelerated by posting and paid ads features. These key findings led to the proposal of sales increment, customer retention and viral marketing as the three indicators of social media effectiveness in strategic planning evaluation. Further detailed measurement criteria have been recommended based on each indicator.

This paper's context is limited to microenterprises in developing market through a subjective-based strategic planning evaluation framework. The social media effectiveness indicators are developed through the perspective of F\&B industry with selective marketing mix elements. Further research is necessary to validate the proposed indicators before any subsequent measurement or advanced data analytics are adopted. The views of owner-managers who operated more than one outlet could either depict a single aspect or holistic representation of other outlets under their ownership or management.

Data collection in this paper involved back translation as majority of the participants prefer answering in Chinese or have limited English comprehension. As this paper is exploratory, the scope can be extended to other popular social media platforms such as Instagram, Twitter or Foursquare and to rural areas or small towns in less developed regions which may yield possible new dimensions.

\section{Practical Implications for Asian Businesses}

Considering the measures highlighted in this paper, Asian microenterprises should be aware of the existing macro-environmental factors which they are operating in. As the context of the research was conducted in a near-developed country, managers in underdeveloped, developing or developed regions or countries in Asia should align certain recommendations accordingly to oversee the best fit in their existing operations. Since the proposed indicators for the social media effectiveness are subjective-based, microenterprises are expected to refine their measurement preferences to a more concrete, objective-based approach. 
More importantly, the most suitable choice of social media platform must be predetermined as not every consumer in Asia have homogenous preference be it Facebook, Instagram, Twitter, LinkedIn, Snapchat, WeChat, LINE or Kakaotalk. Not only that, microenterprises should consider the unique demographic social media preference of their target markets as well especially the younger generational cohorts and their digital-centric lifestyle. Consequently, Internet or mobile usage penetration and trends in using social media platforms are not consistent across Asia so this is another angle that owners or managers should ponder (Ting et al, 2018; Ting et al, 2016). Seasonal variations and their impact on consumer habits is another factor worth taking account into. Social media promotional strategies in colder climate versus warmer climate differ greatly. Ultimately, it is in the hands of the owner or manager who is expected to possess advanced knowledge about this varying consumer preferences.

Despite Ho's (2017) contention that Asian microenterprises preferred to rely on networking as an alternative planning coordination channel, the enormous potential of Facebook promotion in Malaysian F\&B should not be underestimated. Microenterprises that do not seek out Facebook ought to reconsider their decision due to the immense promotional outreach impact it provided to $F \& B$ outlets which participated in this study. The task of managing the Facebook digital contents could be outsourced or assigned to an existing or new staff depending on the budget limit. Use of dual or triple language posting is recommended to augment wider sociodemographic coverage. In the specific context of urban F\&B in Sarawak, Chinese and English would be attractive appeal with the option of localised Malay (Bahasa Sarawak). Audio visual such as live video broadcast of highlighted events or occasions could further attract more customers in complementing the existing Facebook written posts or posted pictures if customer privacy concerns are adequately addressed. Adding the location and direction guide of the outlet would greatly improve customer exposure and awareness.

Microenterprises owners or managers who typically lacked advance education or expertise could further educate themselves through the wealth of strategic-related information in Google to supplement their instinct or existing business experience. An alternative option is registering for one-off modular business courses or certificate programmes via trainings or online learning. Even though most of the contents on social media strategies for small businesses are in English, a few Chinese or Malay language sites were available to fulfil the needs of those who have lower or little command of English. In Asian culture, an emblematic mind set of being inferior due to lower educational level should ideally be eliminated by owner-managers and substituted by knowledge gained from online research efforts. 


\section{References}

Akar, E., \& Topcu, B., (2011), "An examination of the factors influencing consumers' attitudes toward social media marketing", Journal of Internet Commerce, vol. 10, no. 1, pp. 35-67.

Alarcon, M. C., Rialp, A., \& Rialp, J., (2015), "The effect of social media adoption on exporting firms' performance", In Zou, S., Xu, H. \& Shi, L. H., (Eds.), Entrepreneurship in international marketing, Emerald Group Publishing, London.

Antoniadis, I., Paltsoglou, S., Vasios, G., \& Kyratsis, P., (2020), "Online engagement factors on posts in food Facebook brand pages in Greece", Strategic Innovative Marketing and Tourism, pp. 365-373.

Au, A., \& Tucker, J., (2018), "Blue Ocean Strategy for Microenterprises", International Journal of Information, Business and Management, vol. 10, no. 2, pp. 92-98.

Back, M. D., Stopfer, J. M., Vazire, S., Gaddis, S., Schmukle, S. C., Egloff, B., \& Gosling, S. D., (2010), "Facebook profiles reflect actual personality, not self-idealization", Psychological Science, vol. 21, pp. 372-374.

Baer, J., (2015), "11 mind-blowing reasons your company needs Facebook", Retrieved from http://www.convinceandconvert.com/social-media-tools/11-reasons-your-companyneeds-facebook/

Baruah, T. D., (2012), "Effectiveness of Social Media as a tool of communication and its potential for technology enabled connections: A micro-level study", International Journal of Scientific and Research Publications, vol. 2, no. 5,1 pp. 1-10.

Bellamy, L., Lodorfos, G., \& Dana, L-P., (2013), "Micro-politics and strategy formation in SMEs", International Journal of Entrepreneurship and Small Business, vol. 20, no. 3, pp. 26-34.

Bergstrom, T., \& Backman, L., (2013), "Marketing and PR in social media: How the utilization of Instagram builds and maintain customer relationships", Retrieved from http://www.divaportal.org/smash/get/diva2:625012/FULLTEXT01.pdfdate=2013publisher=Stockholm

Boyd, D., (2011), "Social network sites as networked publics: Affordances, dynamics, and implications", Networked Self: Identify, Community, and Culture on Social Network Sites, pp. 39-58.

Bruton, G. D., Ahlstrom, D., \& Si, S., (2015), "Entrepreneurship, poverty and Asia: Moving beyond subsistence entrepreneurship", Asia Pacific Journal of Management, vol. 32, no. 1 , pp. 1-22.

Bryson, M. J., Edwards, H. L., \& Van Slyke, M. D., (2017), "Getting strategic about strategic planning research", Public Management Review, vol. 20, no. 3, pp. 317-339.

Capterra, (2020), "Social media management software", Retrieved from https://www.ca pterra.com/social-media-management-software/

Capua, I. D., (2012), "A literature review of research on Facebook use", The Open Communication Journal, vol. 6, pp. 37- 42.

Casillas, J. C., \& Acedo, F. J., (2013), "Speed in the internationalization process of the firm", International Journal of Management Reviews, vol. 15, pp. 15-29.

Chaffey, D., \& Chadwick, E. F., (2012), Digital marketing, Pearson Education, Harlow.

Cham, T. H., Lim, Y. M., Aik, N. C., \& Tay, A. G. M., (2016), "Antecedents of hospital brand image and the relationships with medical tourists' behavioural intention", International Journal of Pharmaceutical and Healthcare Marketing, vol. 10, no. 4, pp. 412-431.

Cham, T. H., Lim, Y. M., Sia, B. C., Cheah, J. H., \& Ting, H., (2020), "Medical tourism destination image and its relationship with the intention to revisit: A study of Chinese medical tourists in Malaysia", Journal of China Tourism Research, pp. 1-29.

Cham, T. H., Low, S. C., Lim, C. S., Aye, A. K., \& Ling, R. L. B., (2018), "The preliminary study on consumer attitude towards fin-tech products and services in Malaysia", International Journal of Engineering \& Technology, vol. 7, no. 29, pp. 166-169. 
Cheah, J. H., Ting, H., Cham, T. H., \& Memon, M. A., (2019), "The effect of selfie promotion and celebrity endorsed advertisement on decision-making processes: A model comparison", Internet Research, vol. 29, no. 3, pp. 552-577.

Cheing, A., (2018), "Strategic planning in small enterprises on shaping the competitive advantage of boutique hotels in Sabah and Sarawak", Unpublished PhD Thesis, Asia e University, Subang Jaya, Malaysia.

Ciprian, P., (2012), "The growing importance of social media in business marketing", Quaestus Multidisciplinary Research Journal, pp. 94-98.

Clark, M., \& Melancon, J., (2013), "The influence of social media investment on relational outcomes: A relationship marketing perspective", International Journal of Marketing Studies, vol. 5, no. 4, pp.132-142.

Curran, K., Graham, S., \& Temple, C., (2011), "Advertising on Facebook", International Journal of E-Business Development, vol. 1, no. 1, pp. 26-33.

Deepa, N., \& Deshmukh, S., (2013), "Social media marketing: The next generation of business engagement", International Journal of Management Research and Reviews, vol. 3, no. 2, pp. 2461-2468.

Deutscher, F., Zapkau, F. B., Schwens, C., Baum, M., \& Kabst, R., (2016), "Strategic orientations and performance: A configurational perspective", Journal of Business Research, vol. 69, no. 2, pp. 849-861.

Dutta, S., (2010), "What's your personal social media strategy?", Harvard Business Review, vol. 88 , no. 11 , pp. 127-130.

Eggers, F., Kraus, S., Hughes, M., Laraway, S., \& Snycerski, S., (2013), "Implications of customer and entrepreneurial orientations for SME growth", Management Decision, vol. 51, no. 3, pp. 524-546.

Evans, D., (2012), Social media marketing: An hour a day, Wiley, Indianapolis.

Grunig, R., \& Kuhn, R., (2018), The strategy planning process: Analyses, options, projects, Springer-Verlag, Berlin.

Ho, S., (2017), "Formal strategic planning: The Malaysian Chinese business perspective", Malaysian Management Review, vol. 52, no. 1, pp. 11-24.

Hoffman, D. L., \& Fodor, M., (2010), "Can you measure the ROI of your social media marketing”, MIT Sloan Management Review, vol. 51, no. 1, pp. 41-49.

Holloman, C., (2013), The social media MBA in practice. Wiley, Chichester.

Hsieh, L., Child, J., Narooz, R., Elbanna, S., Karmowska, J., Marinova, S., Puthussery, P., Tsai, T., \& Zhang, Y., (2018), "A multidimensional perspective of SME internationalization speed: The influence of entrepreneurial characteristics", International Business Review, vol. 28, no. 2, pp. 268-283.

Ismagilova, E., Dwivedi, Y. K., \& Slade, E., (2019a), "Perceived helpfulness of eWOM: Emotions, fairness and rationality", Journal of Retailing and Consumer Services, vol. 53, pp. 1-13.

Ismagilova, E., Slade, E., Rana, N. P., Dwivedi, Y. K. (2019b), "The effects of characteristics of source credibility on consumer behaviour", Journal of Retailing and Consumer Services, vol. 53, pp. 1-9.

Jaichuen, N., Vongmongkol, V., Suphanchaimat, R., Sasiwatpaisit, N., \& Tangcharoensathien, V. (2019), "Food marketing in Facebook to Thai children and youth: An assessment of the efficacy of Thai regulations", International Journal of Environmental Research and Public Health, vol. 16, no.7, pp. 1-15.

Kaplan, A. M., \& Haenlein, M., (2010), "Users of the world, unite! The challenges and opportunities of social media", Business Horizons, vol. 53, no. 1, pp. 59-68.

Klassen, M. K., Borieis, E., Brennan, L., Reid, M., McCaffrey, T., \& Lim, S. C. M., (2018), "What people "like": Analysis of social media strategies used by food industry brands, lifestyle brands, and health promotion organizations on Facebook and Instagram", Journal of Medical Internet Research, vol. 20, no.6, pp. 1-9.

Korsten, P. J., Lesser, E., \& Cortada, J. W., (2013), "Social business: An opportunity to transform work and create value", Strategy \& Leadership, vol. 41, no. 3, pp. 20-28. 
Kotler, P., Armstrong, G., Harris, L., \& Piercy, N., (2013), Principles of marketing European edition, Pearson Education, London.

Kraus, S., Kauranen, I., \& Henning R. C., (2011), "Identification of domains for a new conceptual model of strategic entrepreneurship using the configuration approach", Management Research Review, vol. 34, no. 1, pp. 58-74.

Kunz, M. B., \& Hackworth, B. A., (2011), "Are consumers following retailers to social networks?", Academy of Marketing Studies Journal, vol. 15, no. 2, pp. 1-22.

Kwok, L., \& Yu, B., (2012), "Spreading social media messages on Facebook: Analysis of restaurant business-to-consumer communications", Cornell Hospitality Quarterly, vol. 20, no. 10, pp. 1-11.

Lal, B., Ismagilova, L., Dwivedi, K. Y., \& Kwayu, S., (2020), "Return on investment in social media marketing: Literature review and suggestions for further research", Digital and Social Media Marketing, pp. 3-17.

Luoma, A. M., (2015), "Revisiting the strategy-performance linkage: An application of an empirically derived typology of strategy content areas", Management Decision, vol. 53, no. 5, pp. 1083-1106.

Marshall, C., \& Rossman, G. B., (2011), Designing qualitative research, Sage Publications, Thousand Oaks.

Mazzarol, T., \& Reboud, S., (2020), "Planning, business models and strategies", Entrepreneurship and Innovation, pp. 191-225.

Minkiewicz, J., Evans, J., \& Bridson, K., (2014), "How do consumers co-create their experiences? An exploration in the heritage sector", Journal of Marketing Management, vol. 30, no. 1-2, pp. 30-59.

Morgan, T., Anokhin, S., Kretinin, A., \& Frishammar, J., (2015), "The dark side of the entrepreneurial orientation and market orientation interplay: A new product development perspective", International Small Business Journal, vol. 33, no. 7, pp. 731-751.

Needles, A., \& Thompson, G. M., (2013), "Social media use in the restaurant industry: A work in progress", Cornell Hospitality Report, vol. 13, no. 7, pp. 6-16.

Pansari, A., \& Kumar, V., (2017), "Customer engagement: the construct, antecedents and consequences", Journal of Academy of Marketing Science, vol. 45, pp. 291-311.

Parveen, F., Jaafar, N. I., \& Ainin, S., (2013), "Social media usage among businesses: A website content analysis", Asian Journal of Information Technology, vol. 12, no. 10, pp. 342-348.

Parveen, F., Jaafar, N. I., \& Ainin, S., (2015), "Social media usage and organizational performance: Reflections of Malaysian social media managers", Telematics and Informatics, vol. 32, no. 1, pp. 67-78.

Peppers, D., \& Rogers, M., (2011), Managing customer relationships, Wiley, New Jersey.

Peters, K., Chen, Y., Kaplan, A. A., Ognibeni, B., \& Pauwels, K., (2013), "Social media metrics-A framework and guidelines for managing social media", Journal of Interactive Marketing, vol. 27, pp. 281-298.

Pfeiffer, M., \& Zinnbauer, M., (2010), "Can old media enhance new media? How traditional advertising pays off an online social network", Journal of Advertising Research, vol. 50, no. 1, pp. 42-49.

Richard, J. E., \& Guppy, S., (2014), "Facebook: Investigating the influence on consumer purchase intention", Asian Journal of Business Research, vol. 4, no. 2, pp. 1-15.

Rossi, P., Lipsey, M., \& Henry, G., (2018), Evaluation: A systematic approach, Sage Publications, Thousand Oaks.

Roy, C. K., Hasan, S., Sadri, M. A., \& Cebrian, M., (2020), "Understanding the efficiency of social media based crisis communication during hurricane Sandy", International Journal of Information Management, vol. 52, pp. 1-13.

Sarawak Tourism, (2019), "Attractions: Food and nightlife", Retrieved from https://sarawakt ourism.com/attractions_type/food-nightlife/

Schulze, C., Scholer, L., \& Skiera, B., (2014), "Not all fun and games: Viral marketing for utilitarian products", Journal of Marketing, vol. 11, no. 78, pp. 1-19. 
Shaltoni, A. M., \& West, D. C., (2010), "The measurement of e-marketing orientation (EMO) in business to-business markets", Industrial Marketing Management, vol. 39, no. 7, pp. 1097-1102.

Stelzner, A. M., (2014), "Social media marketing industry: How marketers are using social media to grow their businesses", Social Media Examiner, pp.1-50.

SME Corp Malaysia, (2016), "Defining SMEs", Retrieved from http://www.smeinfo.com.my /index.php?option=com_content $\&$ view=article \&id=1456\&Itemid=820\&lang=en

Snyder, D., (2013), Social media in the food and beverage industry. Green Hasson Janks \& Food Digest, pp. 1-3.

Thackeray, R., Neiger, B. L., \& Keller, H., (2012), "Integrating social media and social marketing a four-step process", Health Promotion Practice, vol. 13, no. 2, pp. 165-168.

Ting, H., Wong, W. P. M., de Run, E. C., \& Lau, S. Y. C., (2015), "Beliefs about the use of Instagram: An exploratory study", International Journal of Business and Innovation, vol. 2, no. 2, pp. 15-31.

Ting, H., de Run, E. C., Liew, S. L., (2016), "Intention to use Instagram by generational cohorts: The perspective of developing markets", Global Business and Management Research: An International Journal, vol.8, no.1, pp. 43-55.

Ting, H., Lim, T. Y., de Run, E. C., Koh, H., \& Sahdan, M., (2018), "Are we Baby Boomers, Gen X and Gen Y? A qualitative inquiry into generational cohorts in Malaysia", Kasetsart Journal of Social Sciences, vol. 39, no.1, pp.109-115.

Ting, C. Y., Ismail, M. B., Ting, H., Bahri, S. B., Sidek, A. B., Tan, R. T. H., Abu Seman, S., Sethiaram, M., Md Ghazali, M., Lim, Q., Mohd Zaki, M., \& Sohot, M., (2019), "Consumer behaviour towards pharmaceutical products: A model development", International Journal of Pharmaceutical and Healthcare Marketing, vol.13, no.3, pp.387-402.

Trainor, J. K., (2012), "Relating social media technologies to performance: A capabilitiesbased perspective", Journal of Personal Selling \& Management, vol. 32, no. 3, pp. 317331.

Valos, J. M., Mavondo, T. F., \& Munyaradzi W. N., (2017), "How do alternative strategic orientations influence social media performance?", Journal of Strategic Marketing, vol. 27, no. 1, pp. 1-20.

Wilson, C., Brubaker, P., \& Smith, B., (2020), "Cracking the snap code: Understanding the organizational and technological influences of strategic social media adoption", International Journal of Strategic Communication, vol. 14, no. 1, pp. 41-59.

Wu, J. N., Zhong, W. J., \& Mei, S. E., (2011), "Application capability of e-business, ebusiness success, and organizational performance: Empirical evidence from China", Technological Forecasting and Social Change, vol. 78, no. 8, pp. 1412-1425.

Wolf, C., \& Floyd, S. W., (2013), "Strategic planning research: Towards a theory driven agenda", Journal of Management, vol. 43, no. 6, pp. 1754-1788.

Wright, P. R., Paroutis, E. S., \& Blettner, P. D., (2013), "How useful are the strategic tools we teach in business schools?", Journal of Management Studies, vol. 50, no. 1, pp. 92-99.

Zhou, T., Li, H., \& Liu, Y., (2010), “The effect of flow experience on mobile SNS users' loyalty”, Industrial Management \& Data Systems, vol. 111, no. 6, pp. 930-946. 